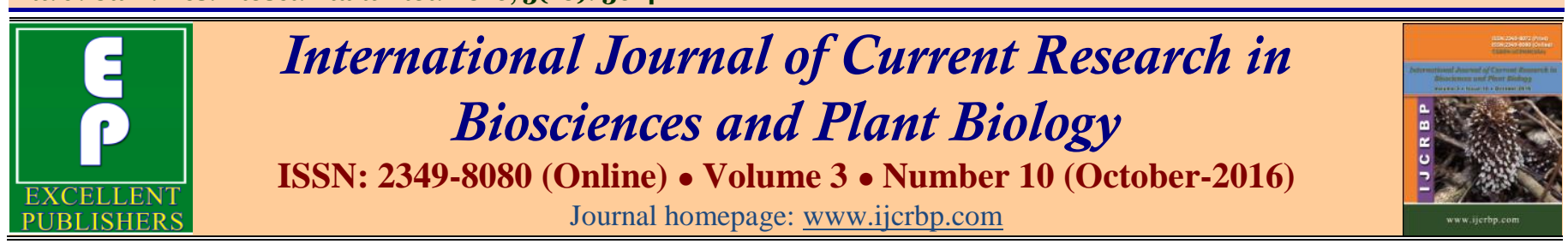

\title{
Screening of Allelopathic Activity of Strychnos nux-vomica L. on the Germination and Seedling Survival of Solanum trilobatum L. in Tamil Nadu, India
}

\author{
C. Alagesaboopathi* \\ Department of Botany, Government Arts College (Autonomous), Salem - 636 oo7, Tamil Nadu, India \\ *Corresponding author.
}

\section{A bstract}

The allelopathic effects of Strychnos nux-vomica L. on seed germination and seedling growth of medicinal plant Solanum trilobatum L. Leaf and bark aqueous extracts of Strychnos nux-vomica at 5,10,15, 20 and 25\% concentrations were applied to effect their determine on seed germination and seedling growth of test plant under laboratory conditions. Germination and seedling growth tests were performed as CRD (Completely Randomized Design) with 3 replications. The aqueous extracts from leaf and bark had inhibitory effect on seed germination of Solanum trilobatum. The results showed that the extracts brought about considerable inhibition in the germination of Solanum trilobatum seeds and in the growth of its root length and shoot length. The allelopathic effect of leaf and bark extracts of Strychnos nux-vomica decreased the seed germination of Solanum trilobatum with increase in the extracts concentration. The extracts also inhibited the root length, shoot length and dry weight of Solanum trilobatum seedlings with increase in the extracts concentration compared with control treatments. Aqueous extract of leaves shows the higher inhibition while bark shows the minimum effect on Solanum trilobatum. These result revealed that the inhibitory effect potency be due to the presence of the allelochemicals in the extract of Strychnos nuxvomica from the present investigation. Strychnos nux-vomica leaf extracts were more detrimental than stem bark extracts. The evidence obtained could be used in the progress of bioherbicide for future in the field.
\end{abstract}

\section{Article Info}

Accepted: 15 September 2016

Available Online: 06 October 2016

\section{Keywords}

Allelopathy
Aqueous extract
Germination
Solanum trilobatum
Strychnos nux-vomica

\section{Introduction}

The term "allelopathy" coined by Molish (1937) popularly refers to any direct or indirect effect of the plant on the germination, growth or development of other plants, through the production of chemicals that avoid into the environment (Rice, 1984). Allelopathy is known as the effects of plant(s) on other plant(s) through the discharge of chemical compounds into the environment via leaching, evaporation, spread out from roots and decomposition of plant residues; which has synergic or antagonistic effects such as auto toxicity and isolation (Rice, 1987; Weih et al., 2008).

Allelochemicals are plant secondary metabolites chiefly produced from medicinal and aromatic plants (Delabys et al., 1998); have been indentified, including the alkaloids, glycosides, phenolic acids, flavonoids, terpenoids, glucosinolates and coumarins. These chemical essences (Phytotoxic) are known to be exuded 
by plants to decrease emergence or growth of the other plants; allelopathic effects of these compounds are often noted to occur early in the life cycle, causing inhibition of seed germination and seedling development. These compounds present a extensive extent of mechanisms of activity and interpretations of mechanisms of performance are complicated by the fact that particular compounds can have multiple phytotoxic effects (Einhellig, 2002).

Allelopathic effect of medicinal species is of particular attention in modern years (Han et al., 2008). Fujii et al. (2003) evaluated the allelopathic activities of 239 medicinal species using the "Plant Box Method" and 223 species of them were found to suppress tested plant development, whereas 17 species were enhancing lettuce radicle development. Gilani et al. (2010) also surveyed allelopathic effects of 81 Japanese medicinal plants to find out possible candidates as natural herbicides. Aziz and Fujii (2005) allelopathic potentialities of 14 medicinal plant species grown in plain areas of Pakistan with semi-arid conditions on growth of lettuce (Lactuca sativa).

Medicinal plants have inhibitory effects (Lin et al., 2003) on selected weeds and its allelochemicals inhibiting weed development. Therefore, it was easier to screen allelopathic plants from medicinal ones than other plants possibly because they have the efficiency to assemble particular metabolic compounds treating numerous disorders of manikind (Qasem and Hassan, 2003).

Some plants may suppress germination, emergence and subsequent development of other plants by exuding toxic essences. These essences are called allelopathic chemicals or allelochemicals and the method is called allelopathy (Rice, 1984). Allelopathic chemicals may be distributed widely among organs such as leaves, stems, barks, roots inflorescence, pollen, flowers, fruits and seeds sometimes found in just one or two of such organs (Zeng et al., 2008). Alagesaboopathi (2014) reported that as the concentration of extracts of Erythroxylum monogynum increased, the growth of the plant decreased, Mahmood Dejam et al. (2014) observed that leaves extracts of Eucalyptus globulus significantly decreased germination and seedling growth in egg plant (Solanum melongena L.).

There are many reports allelochemicals from this plant negatively concern plants like Ampelocissus latifolia, Lantana camara, Leucaena leucocephala, Artemisia annua, Rosmarinus afficinalis and Lavandula vera
(Chaudhuri et al., 2015; Enyew and Raja, 2015, Kalpana and Navin, 2015, Rahim et al., 2015). Strychnos nuxvomica $\mathrm{L}$. belongs to the family of Loganiaceae, is found predominantly distributed in India, Sri Lanka, Southeast Asia and Northern America. It is cultivated throughout India. The plant is popularly known as snake wood or Nux-vomica in English (Chitra et al., 2010) and Yetti or Kanjaram in Tamil (Matthew, 1983). In the Indian system of medicine, the medicinal properties of this species have been known for long time.

The seeds of Strychnos nux-vomica are utilized as stimulant, stomachic, purgative, febrifuge, aphrodisiac and antihelmentic (Warrier et al., 1996) and also in curing diabetes, skin disorders, paralysis, nervous disorders asthma, anaemia and constipation (Jain and Defilipps, 1991). The leaves are used for curing ulcers chronic wounds and the root bark in manage of cholera. The entire plant is used for treating eilepsy and digestive disorders. The plant possesses antitumour, antiinflammatory, analgesic and also used as an antidote for snake poison (Grieve, 2007).

Solanum trilobatum is belongs to the family of Solanaceae. It is an important medicinal plant. Solanum trilobatum is a thorny shrub widely distributed in South India. Solanum trilobatum is an extensively used Indian traditional medicine to treat various diseases like bronchial asthma, tuberculosis and respiratory problems (Chopra et al., 1958; Govindhan et al., 2004). This plant is well known in Ayurveda and Siddha systems. The roots, berries and flowers are used to manage cough (Swathy et al., 2010). The leaf and bark are used to treat antibacterial and antifungal activities (Akshara et al., 2016).

To the best of my knowledge there is scarce information about the effects of allelochemicals on the seed germination dynamics and subsequent seedling growth of Solanum trilobatum L. (Thuthuvalai in Tamil). The aim of this study was to evaluate for the first time the possible effects of the Strychnos nux-vomica L. leaves and bark aqueous extract on the seed germination and seedling growth of Solanum trilobatum plants. Hence, the present research was carried out to determine the allelopathic effects Strychnos nux-vomica extracts on Solanum trilobatum. This study was conducted under laboratory conditions.

\section{Materials and methods}

Preparation of aqueous extract Strychnos nux-vomica plants which grew naturally in Pethampatti, Salem 
district of Tamil Nadu, India. Leaf and stem bark were collected at their matured stage on January 20 and February 7, 2015, for the experiment. The parts were brought into the laboratory and each part of the fresh plant was cut into small pieces, shade dried and then ground separately with the help of electronic grinder and made to fine powder. For leaf and stem bark extract, 20 g. leaf and stem bark powder was soaked in $150 \mathrm{ml}$ double distilled water for $48 \mathrm{hrs}$ to get $24 \%$ extract, by dilutions with double distilled water $5,10,15,20$ and $25 \%$ concentrations of extracts were prepared.

\section{Treatments and experimental design}

Fresh seeds of Solanum trilobatum were collected from the Kanjamalai Hills and road sides of the Pethampatti. The seeds of Solanum trilobatum (Tamil - Thuthuvalai, English - Climbing Brinjal, Purple fruited Pea egg plant) were surface sterilized with $0.2 \%$ mercuric chloride for 1 min. to eliminate the pathogens on the seeds. Then the seeds were to remove the mercuric chloride. The seeds were soaked in various concentrations $(5,10,15,20$ and $25 \%$ ) of extracts for $24 \mathrm{hrs}$. The trial was done in $9 \mathrm{~cm}$ diameter lined with sterile cotton were used for germination trial. Each Petri dish contained 10 uniform sized seeds, while distilled water was added to the untreated control $(0 \%)$. The treatments were arranged in a Completely Randomized Design (CRD) with three replicates kept at room temperature on laboratory bench. The whole experiment was repeated once.

\section{Physical parameters}

Seed germination counts were noted daily for fifteen days. After fifteen days, the seedling root length $(\mathrm{cm})$, shoot length $(\mathrm{cm})$, fresh weight and dry weight were determined $(\mathrm{mg})$. The root and shoot length were determined manually while the fresh weight and dry weight with the help of 4 digital balance of Shimadzu Corporation (Japan).

\section{Statistical analysis}

After twenty days, the seedling root length, shoot length, fresh weight and dry weight were determined. The data obtained were analysed by factorial analysis of variance (ANOVA) to conclude significant $(p<0.05)$.

\section{Results and discussion}

It the present study, leaf and stem bark aqueous extracts of Strychnos nux-vomica inhibited the seed germination of Solanum trilobatum. The inhibitory effect was increased with increasing concentration of the extracts. Maximum inhibitory effect was notable with concentrated leaf extracts. Highest inhibition (80\%) was accounted with concentrated leaf extract. Leaf and stem bark aqueous extracts of Strychnos nux-vomica on Solanum trilobatum noted a moderate reduction in all parameters. The decrease in percent Solanum trilobatum seed germination in the Strychnos nux-vomica leaf aqueous extract treatments ranged between 20 to $35 \%$ compared to $86 \%$ germination in the control. The decrease in germination percentage of Solanum trilobatum seed germination in the Strychnos nux-vomica stem bark aqueous extract treatments ranged between 25 to $40 \%$ compared to $90 \%$ germination in the control (Tables 1 and 2).

Table 1. The effects of Strychnos nux-vomica L. aqueous extracts of leaf on germination and growth of Solanum trilobatum L.

\begin{tabular}{lllllc}
\hline $\begin{array}{l}\text { Treatment with } \\
\text { plant Extract }\end{array}$ & Germination $(\%)$ & Root length $(\mathbf{c m})$ & Soot length $(\mathbf{c m})$ & Fresh weight $(\mathrm{g})$ & Dry weight $(\mathrm{g})$ \\
\hline Control & $86 \pm 4.7$ & $2.5 \pm 0.4$ & $3.6 \pm 0.5$ & $0 \pm 0.15$ & $0 \pm 0.029$ \\
$5 \%$ & $35 \pm 1.4$ & $1.1 \pm 0.6$ & $2.9 \pm 0.2$ & $0 \pm 0.13$ & $0 \pm 0.020$ \\
$10 \%$ & $30 \pm 5.3$ & $1.4 \pm 0.3$ & $3.0 \pm 0.8$ & $0 \pm 0.14$ & $0 \pm 0.019$ \\
$15 \%$ & $30 \pm 6.1$ & $1.8 \pm 0.5$ & $2.1 \pm 0.4$ & $0 \pm 0.12$ & $0 \pm 0.015$ \\
$20 \%$ & $25 \pm 3.5$ & $1.9 \pm 0.2$ & $2.3 \pm 0.5$ & $0 \pm 0.13$ & $0 \pm 0.11$ \\
$25 \%$ & $20 \pm 6.2$ & $1.4 \pm 0.8$ & $2.6 \pm 0.3$ & $0 \pm 0.10$ & $0 \pm 0.008$ \\
\hline
\end{tabular}

The seed germination, root and shoot length was inhibited in entire concentrations (Tables 1-2). The decrease was concentration dependent. The aqueous extracts of two extracts also delayed the shoot lengths of Solanum trilobatum (Tables 1-2). The degree of retardation also increased with raise in the concentrations of the extracts. Statistical analysis at
$5 \%$ level (t-test) revealed that apart from comparison between 5 and $25 \mathrm{~g}$ extract concentrations, there were no significant differences in the growth length of root in the varying extract concentrations as well as those of the control in leaf and stem bark extracts. The extracts of Strychnos nux-vomica also caused significant reduction in seedling development of 
Solanum trilobatum. The extracts not only decreased the shoot and root length of Solanum trilobatum seedlings but also reduced the fresh and dry weight. The reduction in the fresh and dry weight may be due to stunted scanty vegetative development of Solanum trilobatum seedling. This reduction may be due to phytotoxic activity of phytochemical constituents present in aqueous extracts of Strychnos nux-vomica.

Table 2. The effects of Strychnos nux-vomica L. aqueous extracts of stem bark on germination and growth of Solanum trilobatum L.

\begin{tabular}{llllll}
\hline $\begin{array}{l}\text { Treatment with } \\
\text { plant Extract }\end{array}$ & Germination $(\%)$ & Root length $(\mathbf{c m})$ & Shoot length $(\mathbf{c m})$ & Fresh weight $(\mathrm{g})$ & Dry weight (g) \\
\hline Control & $90 \pm 2.4$ & $2.7 \pm 0.6$ & $3.8 \pm 0.2$ & $0 \pm 0.17$ & $0 \pm 0.029$ \\
$5 \%$ & $40 \pm 3.7$ & $1.6 \pm 0.5$ & $3.1 \pm 0.4$ & $0 \pm 0.15$ & $0 \pm 0.025$ \\
$10 \%$ & $35 \pm 2.1$ & $1.5 \pm 0.3$ & $2.5 \pm 0.6$ & $0 \pm 0.14$ & $0 \pm 0.021$ \\
$15 \%$ & $33 \pm 1.5$ & $1.6 \pm 0.7$ & $2.4 \pm 0.8$ & $0 \pm 0.13$ & $0 \pm 0.019$ \\
$20 \%$ & $30 \pm 2.3$ & $1.9 \pm 0.3$ & $2.3 \pm 0.4$ & $0 \pm 0.12$ & $0 \pm 0.015$ \\
$25 \%$ & $25 \pm 4.2$ & $1.6 \pm 0.5$ & $2.5 \pm 0.5$ & $0 \pm 0.11$ & $0 \pm 0.010$ \\
\hline
\end{tabular}

The result of present study proved that the leaf and stem bark extracts of Strychnos nux-vomica was inhibitory in Solanum trilobatum. Alagesaboopathi (2014) reported that leaves and stem extracts of Erythroxylum monogynum significantly decreased germination and seedling development of Solanum lycopersicum Mill. var. PKM-1. Similar results have been noted by Namkeleja et al. (2014). Some current studies indicating the allelopathic effect of aqueous extracts of medicinal plants include. Artemisia annua, Rosmarinus officinalis and Lavandula vera (Rahim et al., 2015), Ricinus communis (Saadaoui et al., 2015), Eruca sativa, Mentha peperina, and Coriandrum sativum (Ali Baeshen, 2014), and Andrographis paniculata (Alagesaboopathi, 2011).

Phytotoxic substances in plants can be released into soil, either as exudates from living plant tissues or by decomposition of plant residues and act as allelopathic substances which inhibit seed germination, seedling establishment and plant development (Belz, 2007). All these investigations indicated the release of phytotoxic chemicals during the preparation of aqueous extracts. Based on this studies were further extended to research the impact of Strychnos nux-vomica leaves and stem bark, as they possessed larger phytotoxicity on the emergence and development of Solanum trilobatum.

Allelopathy has been implicated to be capable in various cases for no germination, stunted progress and sometimes out correct remove of plants (Inderjit and Duke, 2003). Allelochemical play of plants is measures by the sensitivity of roots in the bioassay (Heisey, 1990).

The results are in similarity with previous studies reporting that effectiveness of receiver plants to allelochemicals was concentration dependent of inhibitory essences with a confirmation threshold
(An et al., 2005). The results appeared to be in agreement with that of Swaminathan et al. (1989) who noted that the potential compounds, which are responsible to influence inhibitory determine on germination, are identified a phenolic acids. The release of phenolic compounds adversely affects the germination and development of plants through their interference in energy metabolism, cell division, mineral uptake and biosynthetic processes (Rice, 1984).

The studies of Dias et al. (2005) appeared that the extracts of some plants inhibit the growth of others. With notice to allelopathic effects of plant secondary metabolites, it is now usually recognised that some terpenoids, chiefly monoterpenes and sesquiterpenes present in the volatile fraction (Fischer, 1991) and phenolic compounds are the chief responsible for growth inhibition of competing plants (Harborne, 1993).

Polyphenol compounds such as flavonoids, tannins, and phenolic acids were the highest notable compounds of the crude extracts investigated and could contribute to the germination and growth inhibitory action of the Hypericum species extracts (Dall' Agnol et al., 2003). Various flavonoids such as rutin, quercetin, isoquercitrin and quercetrin among several others have shown effects on plant growth (Iqbal et al., 2005).

The aqueous leaf and stem bark extracts of $S$. nuxvomica showed inhibitory effects on seeds germination, shoot length, root length, fresh weight and dry weight of $S$. trilobatum. The S. nux-vomica leaf and stem bark extracts inhibited the germination and growth of $S$. trilobatum in the present investigation. Hence, they must have been responsible for the inhibition of seed germination, growth and dry matter collection of root and shoot of the plant were progressively decreased with 
the heighten in the concentration of the extract. Further studies are essential to isolate and characterize the supposed allelochemicals in $S$. nux-vomica and the interaction that could be pointing out for the observed inhibition of seed germination and plant progress.

\section{Conclusion}

In conclusion, the concentration dependent inhibitory properties of the aqueous leaf and stem bark extracts of S. nux-vomica on the germination and seedling survival of Solanum trilobatum suggest that the plant has allelopathic activity and receive allelochemicals. These allelochemicals could be the vital purpose for the restricted development of other plant species near their colony. Isolation and characterization of those allelochemicals from Strychnos nux-vomica could be show as manage for the progress of biodegradable environment amicable invention authentic herbicides and equivalent it for chemical herbicides for sustainable weed manage. However, vast research is needed to further promise the allelopathic potential of Strychnos nux-vomica and laboratory and filed experiments. This investigation revealed that the aqueous leaf and stem bark extract of Strychnos nux-vomica has significantly inhibited the seed germination, seedling growth, dry and fresh weight of Solanum trilobatum.

\section{Conflict of interest statement}

Author declares that there is no conflict of interest.

\section{References}

Akshara, R., Elakiya, C., Muthukumaran, P., Saraswathy, N., 2016. Comparative evaluation of antibacterial antifungal activity and phytochemical screening of leaf and bark extract of Solanum trilobatum L. J. Chem. Pharm. Res. 8(7), 198-202.

Alagesaboopathi, C., 2011. Allelopathic effects of Andrographis paniculata Nees. on germination of Sesamum indicum L. Asian J. Exp. Biol. Sci. 2(1), 147150.

Alagesaboopathi, C., 2014. Allelopathic effect of aqueous extract of Erythroxylum monogynum Roxb. on germination and growth of Solanum lycopersicum Mill. var. PKM-1. Int. J. Sci. Res. 3(8), 1091-1094.

Ali Baeshen, A., 2014. Morphological and elements constituent effects of allelopathic activity of some medicinal plants extracts on Zea mays. Int. J. Curr. Res. Acad. Rev. 2(4), 135-145.

An, M., Prately, J.E., Haig, T., Liu, D.L., 2005. Whole range assessment: A simple method for analysis allelopathic dose response data. Nonlinearity Biol. Taxicol. Med. 3,
245-259.

Aziz, M., Fujii, Y., 2005. Allelopathic effect of some medicinal plant substances on germination of Amaranthus retroflexus and Portulaca. In: Proceeding of International Symposium on Improving the Performance of Supply Chains in the Transitional Economics. ISHS Acta Hortic. $699 \mathrm{p}$.

Belz, R.G., 2007. Allelopathy in crop/weed interactions an update. Pest Manag. Sci. 63, 308-326.

Chaudhuri, A., Kundu, L.M., Dutta, S., Chatterjee, S., Goswami, S., Roy, G.C., Ray, S., 2015. Allelopathic effects of aerial parts aqueous extract of Ampelocissus latiflia (Roxb.) Planch. in apical meristem cells. Asian J. Plant Sci. Res. 5(3), 11-16.

Chitra, V., Venkata, K.R.CH.H., Varma, P., Krishna Raju, M.V.R., Jeya Prakash, K., 2010. Study of antidiabetic and free radical scavenging activity of the seed extract of Strychnos nux-vomica. Int. J. Pharm. Pharmaceut. Sci. 2(Suppl.1), 106-110.

Chopra, R.N., Nayar, S.L., Chopra, I.C., 1958. Glossary of Indian Medicinal Plants. Sources of Information on Medicinal Plants, CSIR, New Delhi.

Dall'Agnol, R., Ferraqz, A., Bernardi, A.P., Albring, D., Nor, C., Sarmento, L., Lamb, L., Hass, M., Von Poser, G.L., Schapoval, E.E.S., 2003. Antimicrobial activity of some Hypericum species. Phytomed. 10, 141-147.

Delabys, A., Ancay, A., Mermillod, G., 1998. Recherch d'especes vegetdles a proprietes allopathiques Annales dela $17^{\text {th }}$ Conference de Columa, 9, 10, 11 Dijon (Souspresse).

Dias, J.F.G., Cirio, G.M., Miguer, M.D., Muguel, O.G., 2005. Contribuicao estudoal ecopatico de maytenu silicifoliamart ex Reiss. Celastraceae Rev. Bras. Farmacogn. 15, 220-223.

Einhelling, F.A., 2002. The physiology of allelochemical action: clues and views. In: Allelopathy, from Molecules to Ecosystems (Eds.: Reigosa, M. J., Pedrol, N.). Science Publishers, Enfield, New Hampshire.

Enyew, A., Raja, N., 2015. Allelopathic effect of Lantana camara L. behaviour of maize, Zea mays Linn. and wheat, Triticum turgidum Linn. cultivars. Asian J. Agric. Sci. 7(1), 4-10.

Fischer, N.H., 1991. Plant terpenoids as allelopathic agents. In: Ecological Chemistry and Biochemistry of Plant Terpenoids (Eds.: Harborne, J.B., Tomas-Barberan, F.A.). Clarendon Press, Oxford. pp.377-398.

Fujii, Y., Parvez, S.S., Parvez, M.M., Ohmae, Y., Iida, O., 2003. Screening of 239 medicinal plant species for allelopathic activity using sandwich method. Weed Biol. Manag. 3, 233-241.

Gilani, S.A., Adnan, S.M., Shinwari, Z.K., Fujii, Y., Kikuchi, A., Watanabe, K.N., 2010. Phytotoxic studies of medicinal plant species of Pakistan. Pak. J. Bot. 42(2), 987-996.

Govindhan, S., Viswanathan, S., Vijasekaran, V., Alagappan, R., 2004. Further studies on the clinical efficacy of Solanum trilobatum in bronchial asthma. Phytother. Res. 18, 805-809. 
Grieve, M., 2007. A Modern Herbal Medicine-Poisons and Antidotes. Streadmen Shorters Medical Dictonary. 5, 9196.

Han, C.M., Pan, K.W., Wu, N., Wang, J.C., Li, W., 2008. Allelopathic effect of ginger on seed germination and seedling growth of soybean and chive. Sci. Hortic. 116(3), 330-336.

Harborne, J., 1993. Introduction to Ecological Biochemistry. Academic Press, London.

Heisey, R.M., 1990. Allelopathic and herbicidal effects of extracts from tree of heaven (Ailanthus artissima). Am. J. Bot. 77, 662-670.

Inderjit, S., Duke, S.O., 2003. Eco-physiological aspect of allelopathy. Planta. 217, 529-539.

Iqbal, Z., Golisz, A., Furubayashi, A., Nasir, H., Fujii, Y., 2005. Allelopathic Potential of Buckwheat. World Congress of Allelopathy, Wagga wagga, Australia.

Jain, S.K., DeFilipps, R.A., 1991. Medicinal Plants of India. Reference Publ., Inc. Michigan. 849 p.

Kalpana, P., Navin, M.K., 2015. Assessment of allelopathic potential of Leucaena leucocephala (Lam.) De vit on Raphanus sativus L. Int. J. Sci. Res. 5(1), 1-3.

Lin, O., Tsuzuki, E., Sugimoto, Y., Dong, Y., Matsuo, M., Terao, H., 2003. Assessment of dwarf lily turf (Ophiopogon japonicus) dried powders for weed control in transplanted rice. Crop Prot. 22(2), 431-435.

Mahmood Dejam, M., Khaleshi, S.S., Ataollahi, R., 2014. Allelopathic effects of Eucalyptus globulus Labill. on seed germination and seedling growth of egg plant (Solanum melongena L.) Int. J. Farm Allied Sci. 3(1), 81-86.

Matthew, K. M., 1983. The Flora of the Tamilnadu Carnatic. The Rapinat Herbarium, Tiruchirapalli, Tamilnadu, India.

Molish, H., 1937. Der Einfluss einer planze akf die andre Allelopathi. Gustar Fisher, Jena, Germany. pp.64-67.

Namkeleja, H.S., Mokiti, T.C., Nadakideni, P.A., 2014.
Allelopathic effects of Argemone mexicana to growth of native plant species. Am. J. Plant Sci. 5, 1336-1344.

Qasem, R. J., Hassan, A.A., 2003. Herbicidal properties of some medicinal plants against Malva sylvestris and Portulaca oleracea. Agric. Sci. J. 30(1), 84-99.

Rahimi, M., Bidarnamani, F., Shabanipoor, M., 2015. Effects of allelopathic three medicinal plants on germination and seedlings growth of Portulaca oleraceae. Biological Forum Int. J. 7(1), 1520-1523.

Rice, E.L., 1984. Allelopathy. $2^{\text {nd }}$ Edn. Academic Press, New York. pp.1-67.

Rice, E.L., 1987. Allelochemicals: Role in Agriculture and Forestry. Vol.330. American Chemical Society, Washington DC. pp.8-22.

Saadaoui, E., Martin, J.J., Ghazel, N., Romdhane, C.B., Massoudi, N., Cervantes, E., 2015. Allelopathic effects of aqueous extracts of Ricinus communis L. on the germination of six cultivated species. Int. J. Plant Soil Sci. 7(4), 220-227.

Swaminathan, C., Vinayaraj, R.S., Suresh, K.K., 1989. Allelopathic productivities of Acacia nilotica J. Trop. Forest Sci. 2, 56-60.

Swathy, B., Lakshmi, S.M., Kumar, A.S., 2010. Review on herbal drugs for analgestic and anti-inflammatory activities. Int. J. Bio. Pharma. Res. 1(1), 7-12.

Warrier, P.K., Nambiar, V.P.K., Ramankutty, C., 1996. Indian Medicinal Plants. Vol. 5, 202-206.

Weih, M., Didon, V.M.E., Ro-nnberg-Wastijung, A.C., Bjorkman, C., 2008. Integrated agricultural research and crop breeding: Allelopathic weed control in cereals and long-term productivity in perennial biomass crops. Agric. Syst. 97, 99-107.

Zeng, R.S., Malik, A.V., Luo, S.M., 2008. Allelopathy in Sustainable Agriculture and Forestry. Springer Verlag, Germany. 412p.

\section{How to cite this article:}

Alagesaboopathi, C., 2016. Screening of allelopathic activity of Strychnos nux-vomica L. on the germination and seedling survival of Solanum trilobatum L. in Tamil Nadu, India. Int. J. Curr. Res. Biosci. Plant Biol. 3(10), 36-41. doi: http://dx.doi.org/10.20546/ijcrbp.2016.310.005 